Yayın Geliş Tarihi: 23.05.2019

Yayın Onay Tarihi: 28.12.2019

DOI No: $10.35343 /$ kosbed.569351

İbrahim AVCI •

Emel YILDIZ ••

\section{Fenomenlerin Güvenilirlik, Çekicilik ve Uzmanlık Özelliklerinin Marka Tutumu, Satın Alma Niyeti ve Elektronik Kulaktan Kulağa Pazarlama Üzerindeki Etkileri: Instagram Örneği ${ }^{1}$}

Effects of Trustworthiness, Attractiveness and Expertness on Brand Attitude, Purchase Intention and E-Word-of-Mouth Marketing: The Case of Instagram

\title{
Özet
}

Instagram'ın hızı büyümesi ve popüler olması bu platformda fenomen olarak tabir edilen ve dijital dünyanın yeni ünlüleri olarak bilinen kişilerin ortaya çıkmasına zemin hazırlamıştır. Mevcut araştırma da Instagram fenomenleri üzerine gerçekleştirilmiştir. Araştırmanın temel amacı Instagram fenomenlerinin güvenilirlik, uzmanlık ve çekicilik özelliklerinin, tüketicilerin marka tutumu, satın alma niyeti ve elektronik kulaktan kulağa pazarlama davranışı üzerinde etkisinin olup olmadığını belirlemektir. Bu amaçla hazırlanan elektronik anket formu 15.11.2018 - 22.11.2018 tarih aralığında $Y$ jenerasyonu olarak bilinen 18-38 yaş aralığında yer alan 470 Instagram kullanıcısına uygulanmıştır. Elde edilen verilerin analizi neticesinde Instagram fenomenlerinin güvenilirlik ve çekicilik özelliklerinin marka tutumu, satın alma niyeti ve elektronik kulaktan kulağa pazarlama davranışı üzerinde olumlu etkisinin olduğu ancak uzmanlık özelliğinin marka tutumu, satın alma niyeti ve elektronik kulaktan kulağa pazarlama davranışı üzerinde anlamlı bir etkisinin olmadığı sonucuna ulaşılmıştır.

Anahtar Kelimeler: Instagram, Fenomen, Güvenilirlik, Çekicilik, Uzmanlık.

Jel Kodları: M30, M39

\section{Abstract}

Instagram's rapid growth and popularity has paved the way for the emergence of the so-called influencer, known as the new celebrities of the digital world. The current research was carried out on the Instagram Influencers. The main purpose of the study is to determine whether the trustworthiness, attractiveness and expertness features of Instagram influencers have an effect on consumers' brand attitude, purchasing intention, and electronic word of mouth. Electronic questionnaire form which was prepared for this purpose was applied to 470 Instagram users

- Öğr. Gör., Gümüşhane Üniversitesi, Sosyal Bilimler MYO, Yönetim ve Organizasyon Bölümü, ibrahimavcimail@gmail.com ORCID: 0000-0001-9112-5076

•• Dr. Öğr. Üyesi., Gümüşhane Üniversitesi, İ̈BF, emel.yildiz@yahoo.com ORCID: 0000-0001-7190-593X

${ }^{1}$ Bu makale, 18-20 Nisan 2019 tarihlerinde Tiflis'te gerçekleşen Uluslararası Bilimsel Araştırmalar Kongresi 2019 Tiflis isimli kongrede sözlü bildiri olarak sunulmuştur. 
betwen the age of 18-38 years known as $Y$ generation between 15.11.2018-22.11.2018. As a result of analysis of the obtained data, it was found that while trustworthiness and attractiveness have positive effect on brand attitude, purchase intention and Word of mouth, expertness has no significant effect.

Keywords: Instagram, Influencer, Trustworthiness, Attractiveness, Expertness.

Jel Codes: M30, M39

\section{Giriş}

Dünya hızlı bir değişim ve gelişim içerisindedir. Bu değişim ve gelişimin beraberinde getirdiği rekabet, genelde işletmeleri ve özelde ise işletmelere ait markaları bir savaş içerisine itmektedir. Dolayısı ile işletmeler bu savaştan galip çıkmak için müşterilerine ulaşmada farklı pazarlama kanalları ve iletişim yöntemleri kullanmaktadır. Pazarlamanın çıkış sürecinde müşteriler biraz daha geri planda kalırken, günümüzde müşteriler pazarlamanın merkezinde bulunmakta ve artık müşterilerin istek ve ihtiyaçları daha fazla dikkate alınmaktadır. Son dönemlerde sık sık ifade edildiği gibi, yeni müşteri kazanmak, var olan müşteriyi elde tutmaktan daha pahalı olduğu için (Kotler, 2005: 90) mevcut müşteri ile sürekli iletişim halinde olmak gerekmektedir. Günümüz internet çağında ise bu iletişim sürecinin gerçekleştiği kanallardan biri de sosyal medya platformlarıdır. Sosyal medya platformlarının çoğalması ve önem kazanmasıyla markalar müşterileriyle Facebook, Instagram, Twitter gibi sosyal medya platformları aracılığıla iletişim kurmaktadır. Yapılan araştırmalara göre Dünya'da ve Türkiye'de en fazla kullanilan sosyal medya platformları sirasiyla Instagram, Facebook ve Twitter şeklindedir. Günümüzde ise en hızlı büyüyen sosyal medya platformu Instagram'dır (Garifova, 2016: 134). Instagram'ın bu kadar çok kullanıcıya sahip olması ve popüler olması, bu platformda "Fenomen" olarak tabir edilen kişilerin ortaya çıkmasına zemin hazırlamıştır. Gün geçtikçe daha fazla duyulan fenomen terimi, fikir, düşünce ve davranışlarına diğer insanlara göre daha fazla değer verilen kişi olarak tanımlanmaktadır. Fenomen kelimesi bazı kaynaklarda fikir lideri, bazı kaynaklarda kanaat önderi, bazı kaynaklarda ise etkileyici olarak ifade edilmiştir. Bu araştırmada ise fenomen terimi kullanilacaktır.

Fenomenlerin bu kadar önem kazanması etkileyici pazarlamanın da ortaya çıkmasını sağlamıştır (Ewers, 2017: 4). Etkileyici pazarlama faaliyetlerinin artmasıyla fenomen terimi, "Sosyal Medya Fenomeni", "Instagram Fenomeni" şeklinde kullanılmaya başlanmıştır. Instagram fenomeni, Instagram platformunda yüksek takipçi sayısına sahip, bu takipçiler tarafından sevilen, hayran olunan, fikir ve bilgisine önem verilen kişilerdir. Instagram fenomenleri ürettikleri fotoğraf ve video gibi içerikleri paylaşarak takipçileri ile iletişim kurmakta, paylaşılan bu içerikler elektronik kulaktan kulağa pazarlama ile farklı kişilerle paylaşılmakta ve böylelikle Instagram fenomenlerinin takipçi sayısı daha da artmaktadır. Instagram fenomenlerinin bu şekilde önem kazanması, markaların dikkatini çekmiş ve markalar ürün ve hizmet tanıtımlarında Instagram fenomenlerini kullanmaya başlamışlardır. Önceleri herhangi bir markanın 
reklamında sanatçı, futbolcu, uzman gibi ünlüler kullanılırken, günümüzde ürün tanıtım ve reklamlarında Instagram fenomenleri aktif olarak yer almaktadir. Mevcut veya yeni bir ürün ve hizmetin tanıtımı Instagram fenomeni aracılığı ile yapılmakta ve böylelikle ilgili tanıtım mesajı sosyal medya üzerinden birçok takipçiye (tüketiciye) direkt olarak ulaştırılmaktadır. Instagram fenomeninin paylaştığı bu tanıtıcı reklam içeriklerine, fenomenin özelliklerine göre tüketiciler olumlu ya da olumsuz reaksiyon göstermektedir. Literatür incelendiğinde reklamlarda ünlü kullanımının etkilerini belirlemeye yönelik çok fazla araştırmaya rastlanmaktadır. Bu araştırmalarda genellikle reklamda ürün destekçisi olarak yer alan ünlü kişilerin özelliklerinin, marka, tutum ve satın alma niyeti ile ilişkileri araştırılmıştır. Ancak günümüzün popüler ünlüleri olarak bilinen Instagram fenomenlerinin özellikleri ve bu fenomenlerin tüketici davranışları üzerindeki etkilerini araştıran çok fazla araştırma bulunmamaktadır. Literatürdeki bu eksiklikten dolayı, bu araştırmada Instagram fenomenlerinin özelliklerinin tüketici davranışları üzerindeki etkilerine odaklanılmıştır. Bu doğrultuda Ohanian'ın (1990) geliştirmiş olduğu güvenilirlik, uzmanlık ve çekicilik boyutlarından oluşan kaynak güvenilirliği modeli Instagram fenomenlerine uyarlanmıştır.

Araştırmanın amacı kaynak güvenilirliği modeli boyutlarına göre uyarlanan Instagram fenomenlerinin güvenilirlik, uzmanlık ve çekicilik özelliklerinin, tüketicilerin marka tutumu, satın alma niyeti ve elektronik kulaktan kulağa pazarlama davranışı üzerinde etkisi olup olmadığını belirlemektir.

\section{Kavramsal Çerçeve}

\subsection{Fenomen Güvenilirliği ve Boyutları}

Fenomen güvenilirliği kavramının temeli Ohanian'ın (1990) kaynak güvenilirliği modeline dayanmaktadır. Literatürde "Source Credibility" olarak ifade edilen kaynak güvenilirliği, bir iletişim sürecinde alıcının verilen mesajı kabul etmesi üzerinde etkisi olan olumlu özellikleri anlatmak için kullanılan bir kavramdır. Fenomen güvenilirliği kavramı ise, bir kişinin fenomen olarak tabir edilen etkileyici kişilerin fikir ve önerilerini inandırıcı, tarafsız ve gerçek olarak algılamasını ifade etmektedir. Kaynak güvenilirliği modeli çekicilik, uzmanlık ve güvenilirlik olmak üzere 3 boyuttan oluşmaktadır (Ohanian, 1990: 41). Bir reklam, fikir vb. şeylerin etkinliğini, bunları paylaşan kişilerin sahip olduğu bu üç özelliklerin düzeyi belirlemektedir (Rebelo, 2017: 27). Son y1llarda özellikle sosyal psikologların yaptıkları çalışmalarda, güvenilirlik seviyesi yüksek olan kişi veya kaynakların, düşük olanlara göre ikna etme açısından daha önemli olduğu bilinmektedir (Çinkay, 2017: 32). Djafarova ve Rushworth (2016) yaptıkları araştırma sonucunda, ileride yapilacak araştırmaların Instagram platformunda yer alan fenomenleri takip eden kişilerin kaynak güvenilirliğine odaklanmaları gerektiğini savunmuşlardır (Djafarova ve Rushworth, 2016: 7). Dolayısı ile bu araştırmada da fenomenlerin güvenilirlikleri, Ohanian (1990) tarafından literatüre kazandırılan güvenilirlik, uzmanlık ve çekicilik boyutlarını kapsayan model üzerinden araştırılmaktadır.

Güvenilirlik: Kaynak güvenilirliği boyutlarından ilki olan güvenilirlik boyutunu Ohanian (1990), herhangi bir ürünle ilgili olumlu ifadeler söyleyen kişilere yönelik güven ve kabul seviyesi şeklinde tanımlamıştır (Ohanian, 1990: 41). Diğer bir tanıma göre ise 
güvenilirlik, ünlü kişinin sahip olduğu ve tüketiciler tarafından algılanan dürüstlük, haysiyet ve inanılırlığın niteliğidir (Friedman vd., 1976: 23). Tüketiciler herhangi bir ünlü kişiyi güvenilir olarak algıladıklarında, söz konusu kişiden ürünle ilgili gelen mesajlar tüketicilerin tutumlarını değiştirebilmektedir (Amos vd., 2008: 215). Buna örnek olarak Pornpitakpan (2004) yaptığı araştırma sonucunda, mesaj kaynağının güvenilir olmasının marka tutumu üzerinde etkisinin olduğunu ifade etmiştir (Pornpitakpan, 2004: 268). Bu yüzden bir markanın mesajı tanıtılırken, tüketicilerin dürüst, güvenilir ve inanılır olarak algıladıkları ünlüler kullanılabilir (Wang ve Scheinbaum, 2017: 7). Güvenilirlik boyutu, mesaj kaynağının uzmanlığı ve çekiciliği ile de ilişkilidir (Ohanian, 1990: 41). Ancak bir mesaj kaynağına yönelik tutum üzerinde güvenilirliğin, uzmanlığa göre daha etkili olduğu belirlenmiştir (Amos, vd., 2008: 230). Benzer şekilde Ohanian (1990), güvenilir bir iletişimcinin (uzman olsun ya da olmasın) daha ikna edici olduğunu ifade etmiştir (Ohanian, 1990: 50). Hovland vd. (1953) ise, kişinin güvenilir olarak algılanması konusunda, ilk olarak tüketicinin kendisine geçerli bilgilerin sağlandığına inanması, daha sonra bu geçerli bilgilerin bir uzmanlık çerçevesinde desteklenmesi gerektiğini ifade etmiştir (Hovland vd., 1953: 21). Aksi halde tüketici verilen mesajın tam tersine inanıyorsa ve tüketiciye geçerli bilgi iletilemedi ise verilen mesajın reddedilme durumu ortaya çıkmaktadır (Dangi, 2017: 38).

Uzmanlık: Kaynak güvenilirliği boyutlarından ikincisi olan uzmanlık boyutu, mesaj1 ileten kişinin tecrübe, bilgi ve beceri yönünden doğru kaynak olarak algılanmasıdır. Uzmanlık aynı zamanda, yetkili olma, yeterlilik ve uzman gibi kavramlarla da ifade edilmektedir. Eğer ünlü kişi tüketiciler tarafından uzman olarak algılanıyorsa, gerçekten uzman olması gerekmez (Erdoğan, 1999: 298). Uzmanlık, kişinin konu hakkındaki bilgisini, ortaya koyduğu iddaaların doğruluğunu ve tüketiciler tarafından bilgili olup olmadığının algılanmasını göstermektedir (Zang, 2014: 14). Ĕ̆er bir ürün ve hizmetin reklamını yapan kişi, söz konusu ürün ve hizmet ile ilgili bilgili ve tecrübeli değilse, tüketiciler ürün ve hizmete yönelik olumsuz tutum sergilemektedir (Ohanian, 1990: 42). Yapılan bazı araştırmalara göre ise (Speck vd., 1988; Ohanian, 1991; Amos vd, 2008) bir tüketici reklamdaki bir fenomeni uzmanlık seviyesi yüksek olarak algıladığında, reklamdaki mesaj sayesinde ikna edilme ihtimali daha yüksek olmaktadır. Tüketiciler açısından uzmanlık seviyesi yüksek olan bir fenomenin, uzmanlık seviyesi düşük olan bir fenomene göre daha ikna edici olduğu bazı araştırmalarca da desteklemektedir (Ohanian, 1991; Erdoğan, 1999).

Çekicilik: Kaynak güvenilirliği modelinin üçüncü boyutu çekiciliktir. Çekiciliğin, özellikle iletişim sürecinde mesajın etkinliği üzerinde doğrudan etkisi vardır. Çekicilik özellikle fiziki dış görünüşle ilgilidir. Dolayısı ile bir kişi güzel, zarif ve şık olarak algilanıyorsa bu kişi çekicidir (Ohanian, 1990, 42; Amos vd. 2008; 215). Erdoğan'a (1999) göre ise çekicilik sadece fiziki olarak değil, bunu yanı sıra kişilik ve atletik kabiliyet gibi özellikleri de kapsamaktadır (Erdoğan, 1999: 299). Çekiciliğin kendi içinde benzerlik ve tanıdıklık (aşinalık) işlevleri vardır. Benzerlik, ünlü ile tüketici arasındaki benzerliği, tanıdıklık ise tüketicinin ünlü kişiyi tekrar tekrar medyada görerek aşina olmasını ifade etmektedir. Bu iki işlev çekicilik algısını arttırabilir. Çekicilik boyutu sayesinde tüketiciler çekici bir kaynak tarafından sunulan bilgileri benimseyebilirler (Wang ve Scheinbaum, 2017: 8). Örneğin, reklam filminde rol alan bir ünlünün fiziki çekiciliği, tüketiciler 
üzerinde olumlu bir geri bildirim sağlamaktadır (Apeyoje, 2013: 3). Tüketiciler üzerinde ilk olarak ünlünün çekicilik özelliği etkisini göstermekte, daha sonra ünlünün uzmanlığ1 özelliği ön plana çıkarak tüketicileri etkilemektedir (Eisend ve Langner, 2010: 533). Van der Walth vd. (2009), bir konu ile ilgili mesajların etkili olması için bu mesajları iletecek fenomenlerin çekiciliğinin önemli olduğunu ifade etmişlerdir (Van der Walth vd., 2009: 104). Ohanian'a (1990) göre ise, çekici fenomenler tüketicilerin inançlarını değiştirme konusunda daha başarılıdırlar. Çekici olan kişiler çekici olmayan kişilere göre takipçileri tarafından daha çok sevilebilir ve çekici olan kişiler bir ürün ve hizmetle ilgili daha olumlu etki meydana getirebilirler (Ohanian, 1990: 42).

\subsection{Marka Tutumu}

Birçok araştırmaya konu olan marka tutumu ile ilgili farklı tanımlamalar mevcuttur. Mitchell ve Olsen (1981) marka tutumunu kısaca, bir kişinin markayı genel olarak değerlendirmesi şeklinde tanımlamıştır (Mitchell ve Olsen, 1981: 319). Genel olarak değerlendirmenin yanısıra marka tutumu, tüketicilerin markayı nasıl algıladıklarını, marka ile ilgili düşüncelerinin neler olduğunu, marka ile ilgili eğilimlerini göstermektedir (Sheinin vd., 2011: 6). Markaya yönelik tutum, tanitılan veya reklamı yapılan bir marka ile ilgili tüketiciler üzerinde olumlu tutumlar oluşturarak marka seçimini etkileme amacı taşımaktadır (Shimp, 1981: 10). Tüketicinin, birçok marka ile karşılaştığında hangi marka ile ilgili olumlu tutuma sahipse onu seçip, diğer markaları elemesi muhtemeldir (Biehal vd., 1992: 25). Markaya yönelik olumlu bir tutum olmasının, satın alma niyetini ve davranışını olumlu yönde etkilediği ve pazar payını arttırdığı bilinmektedir (Baldinger ve Rubinson, 1996: 32). Yapılan araştırmalarda seçilen ünlü kişilerin sahip olduğu özelliklerin, tüketicilerin markaya yönelik tutumları üzerinde etkisinin olduğu belirlenmiştir (Ewers, 2017: 5). Kaynak güvenilirliği modelindeki boyutlar (güvenilirlik, uzmanlık ve çekicilik), ünlünün yer aldığı markaya yönelik tüketicilerin tutumu ile ilişkilendirilebilir (Wang ve Scheinbaum, 2017: 9). Genel olarak yapılan pazarlama araştırmalarında, marka tutumu tüketici davranışlarını etkileyen güçlü bir faktör olarak görülmektedir (Bozbay vd., 2018: 6).

\subsection{Satın Alma Niyeti}

Satın alma niyeti, bir tüketicinin ürün ya da hizmeti satın alma arzusu (Belch ve Belch, 2004: 120) ve bilinçli olarak plan yapması (Spears ve Singh, 2004: 56) şeklinde tanımlanmaktadır. Satın alma niyeti ayrıca tüketicilerin bilişsel davranışlarının (neden belirli bir ürün, hizmet veya marka satın alma niyetinde oldukları) bir bileşenidir (Ling vd., 2010: 64). Tüketicilerdeki satın alma isteği ne kadar fazla olursa, satın alma işlemini sonlandırma davranışı da o kadar fazla olur (Gruber, 1970: 25). Diğer bir deyişle satın alma niyeti, gerçek satın alma davranışı gösterme konusunda birer göstergedir ve tüketicilerin davranışlarını ölçme konusunda kullanılır (Kim vd., 2008: 421). Dolayısı ile marka sahiplerinin amacı, ünlü kişiler vasıtası ile mevcut müşterileri elde tutmak ve yeni müşterilerin dikkatini çekerek satın alma niyeti oluşturmaktır (Ko vd., 2008: 161). Yapılan araştırmalar (Erdoğan, 1999; Ohanian, 1991; Pornpitakpan, 2004; Van der Waldt vd., 2009) sonucunda fenomenlerin güvenilirliklerinin satın alma niyetini etkilediği belirlenmiştir. Satın alma niyeti, ürün ve hizmetin özelliklerinden, fiyatından ve tanıtımda yer alan ünlü kişinin performansından etkilenmektedir. Kısaca satın alma 
niyetinde olan tüketiciler, hayran oldukları ünlülerden olumlu yönde etkilenmektedir (Freeman ve Chan, 2015: 667).

\subsection{Elektronik Kulaktan Kulağa Pazarlama Davranışı}

Elektronik kulaktan kulağa pazarlama davranışının temelinde "womm" olarak ifade edilen kulaktan kulağa pazarlama yer almaktadır. Tüketici davranışları alanındaki en etkili pazarlama araçlarından biri olarak bilinen kulaktan kulağa pazarlama, bir markanın ürün ve hizmetleri ile ilgili iletişimi olarak tanımlanmaktadır (Arndt, 1967: 291). Daha sonra internetin gelişmesi ve yaygınlaşması sonucunda, yeni pazarlama aracı olarak elektronik kulaktan kulağa pazarlama kullanılmaya başlanmıştır (Kim ve Choi, 2012: 222). Literatürde elektronik kulaktan kulağa pazarlama, eski, fiili ve potansiyel müşterilerin internet ortamında ürün ve hizmetlerle ilgili paylaştıkları olumlu ve olumsuz açıklama şeklinde tanımlanmaktadır (Hennig-Thurau vd., 2004: 39). Elektronik kulaktan kulağa pazarlamanın fiili olarak kullanıldığı platformlar Facebook, Instagram gibi sosyal ağlar, firma web siteleri, ürün inceleme/şikayet siteleri, forum ve bloglar gibi alanlardır (Erkan ve Evans, 2014: 13). Elektronik kulaktan kulağa pazarlama vasıtasıla marka mesajlarının kısa sürede birçok tüketiciye ulaştıralabilmesi pazarlamacılar açısından bir avantajdır (Alboqami vd., 2015: 343). Tüketiciler bir ürün ya da hizmeti satın almadan önce Facebook ve Instagram gibi platformlarda araştırma yapmaktadır (Yan vd., 2013: 63). Dolayısı ile elektronik kulaktan kulağa pazarlama sosyal mecralarda fikir arama, fikir aktarma ve görüş verme şeklinde gerçekleşmektedir (Chu ve Kim, 2011: 50). Elektronik kulaktan kulağa pazarlama iyi yönetildiği takdirde, bir markanın büyüme potansiyeli artar (Park ve Kim, 2007: 400). Bush vd. (2004)’ ne göre bir ürün ya da hizmet, ünlü bir sporcu tarafından onaylandığında olumlu kulaktan kulağa pazarlamanın ortaya çıkması muhtemeldir (Bush vd., 2004: 110). Ünlü kişinin onaylanması için güvenilir, uzman ve çekici olduğu algısı ünlü kişiyi güvenilir bir bilgi kaynağı durumuna getirir (Saleem, 2017: 50).

\section{Literatür}

Literatür incelendiğinde direkt olarak Instagram fenomenlerinin güvenilirlik, uzmanlık ve çekicilik özelliklerinin satın alma niyeti, marka tutumu ve elektronik kulaktan kulağa pazarlama davranışı üzerindeki etkisi ile ilgili çok fazla araştırmaya rastlanamamaktadır. Ancak Ohanian'ın (1990) geliştirmiş olduğu kaynak güvenilirliği modeli ile ilgili çok fazla araştırma litetürde yerini almış ve birçok araştırma tarafından da uyarlanmıştır (Charbonneau ve Garland, 2006; Garland ve Ferkins, 2015; Hamid ve Fern, 2016). Ohanian (1990) ürün destekçisi olarak ünlü kullanımı üzerine geliştirmiş olduğu kaynak güvenilirliği boyutlarının (güvenilirlik, uzmanlık ve çekicilik) satın alma niyeti üzerinde etkisi olduğunu belirlemiştir. Ohanian'dan sonra bu boyutların satın alma niyeti üzerine etkisi araştıran farklı araştırmalar da yapılmıştır (Stanley vd., 2011; Zafar ve Rafique, 2012; Smink, 2013; Shelton ve Chiliya, 2014, Sertoğlu vd., 2014; Wongweeranonchai ve McClelland, 2016; Samat vd, 2016; Wang ve Scheinbaum, 2017; Seiler, 2017; Saleem, 2017). Wongweeranonchai ve McClelland (2016) yapmış oldukları araştırmada, uzmanlık ve çekicilik boyutlarının satın alma niyeti üzerinde etkili olduğunu belirlerken, güvenilirlik boyutunun bir etkisinin olmadığını belirlemişlerdir. Kaynak güvenilirliği boyutunun tamamının satın alma niyeti üzerinde etkisini olduğunu 
belirleyen araştırmalar da vardır (Deshield, 1992; Amos vd., 2008; Stanley vd., 2011; Carvalho, 2012; Pritzen, 2012; Sertoğlu vd., 2014; Chan vd., 2016; Seiler, 2017; Rachbini, 2018; Khalid ve Sidduk, 2018). Renton (2006) ünlülerin çekiciliklerinin ve güvenilirliklerinin satın alma niyetini etkilediğini belirlemiştir. Yapılan araştırmalarda en fazla etkinin güvenilirlik boyutu tarafından sağlandığı belirlenmiştir (Renton, 2006; Ahmed vd., 2014; Chaovalit, 2014; Rachbini, 2018).

Diğerlerinden farklı olarak Tanjung ve Hudrasyah (2016) araştırmalarında, bu boyutları ünlü ve ünlü olmayan kişiler açısından araştırmışlar ve araştırma sonucunda ünlü olan kişilerin çekici olarak algılandıklarını, ünlü olmayan kişilerin ise güvenilir ve uzman olarak algılandıklarını, marka tutumu ve satın alma niyetini etkilediklerini belirlemişlerdir. Benzer şekilde Gaied ve Rached (2010) Tunus'ta yaptıkları araştırmada, reklamda kullanılan ünlü ve ünlü olmayan kişilerin etkisini araştırmışlar ve araştırma sonucunda ünlü olmayan kişiler daha güvenilir olarak bulunmuştur. Aziz vd. (2013) ise, ünlü olanların ünlü olmayanlara göre daha güvenilir olduğunu ve satın alma niyetini etkilediğini belirlemişlerdir. Smink (2013) ise diğerlerinden farklı olarak, mesaj güvenilirliği ile kaynak güvenilirliği arasındaki ilişkileri araştırmış ve her ikisinin de satın alma niyetini etkilediğini belirlemiştir. Shelton ve Chiliya (2014), video oyun karakterlerinin ünlü marka destekçisi olarak kullanılmasını araştırmışlar ve satın alma niyetini etkilediğini belirlemişlerdir. Samat vd. (2016) ise, tüketicilerin çevrimiçi satın alma niyeti üzerinde ünlü güvenilirliğinin etkisinin olduğunu belirlemişlerdir. Benzer şekilde Lisichkova ve Othman (2017), üç boyutun çevrimiçi satın alma niyeti üzerinde etkisinin olduğunu belirlemişlerdir. Willemsen vd. (2012), yaptıkları çalışmada çevrimiçi ürün incelemelerinde algılanan uzmanlık ve güvenilirliğin etkilerini araştırmışlardır. Wei ve Lu (2013) ise kullanılan ünlü kişilerin, kadınların alışveriş davranışları üzerindeki etkisini araştırmışlardır.

Bazı araştırmalarda ise tanıtım ve reklamlarda ünlü kullanımının tüketicilerin satın alma niyetini etkilediği belirlenmiştir. (Malik ve Qureshi, 2016; Çinkay, 2017; Ewers, 2017). Anghel (2009) yaptığı araştırmada farklı bir sonuç bularak, ünlü destekçisi kullanımının hediye alımı esnasında satın alma niyetini etkilemediğini belirlemiştir. Reklamlarda farklı ırklardan ünlü kullanmanın satın alma niyeti üzerindeki etkisini araştıran çalışmalar da vardır (Khan vd., 2016; Wang, 2018; Chekima vd., 2018). Khan vd. (2016), Hindistan ile Pakistan'da gerçekleştirdikleri araştırmada ünlü ve ülke faktörleri arasında çok fazla bir farkın olmadığını belirlemişlerdir. Bu boyutlarla ilgili yapılan araştırmalarda güvenilirlik ve çekicilik boyutlarının satın alma niyetini etkilediği, uzmanlık boyutunun ise satın alma niyetini etkilemediği sonucuna ulaşan çalışmalar da bulunmaktadır (Nhung vd., 2011; Zafar ve Rafique, 2012; Freeman ve Chan, 2015; Emma ve Matilde, 2017; Rebelo, 2017). Yapılan bazı çalışmalarda ise (Schapers, 2013; Messiaen, 2017) Instagram'daki bir fenomenin güvenilirliğinin satın alma niyetini etkilediği belirlenmiştir.

Instagram fenomenlerinin güvenilirliği, çekiciliği ve uzmanlığının marka tutumu üzerine etkisini araştıran çalışmalar da mevcuttur. Bu araştırmaların bazılarında (Amos vd., 2008; Stanley vd., 2011; Dissanayake ve Ismail, 2015; Mumnuka vd., 2016) güvenilirlik, çekicilik ve uzmanlık boyutlarının tamamının marka tutumu üzerinde etkisinin olduğu, bazılarında ise (Renton, 2006; Amelina ve Zhu, 2016; Wang vd., 2017) 
sadece güvenilirlik ve çekicilik boyutunun marka tutumu üzerinde etkisinin olduğu belirlenmiştir. Bazı araştırmalarda ise (Aziz vd., 2013; Seiler ve Kucza, 2017) sadece güvenilirlik boyutunun marka tutumu üzerinde etkisinin olduğu belirlenmiştir. Ibok ve Ibok (2013), ünlülerin etkin olmasında uzmanlığın ve çekiciliğin daha önemli olduğunu belirlemişlerdir. Eisend ve Langner (2010), çekicilik ve uzmanlığın marka tutumu üzerindeki etkisini araştırmış ve sonuçta çekici olan uzmanların marka tutumu üzerinde daha etkili olduğu belirlemişlerdir. Instagram fenomenleri ile ilgili yapılan araştırmalarda (Schapers, 2013; Messiaen, 2017) ise güvenilir olarak algılanan Instagram fenomeninin marka tutumu üzerinde olumlu etkisinin olduğu belirlenmiştir. Doss (2011) ise farklı bir çalışma yaparak, bir markaya yönelik olumsuz tutumun, markayı destekleyen ünlünün güvenilirliği ve uzmanlığını olumsuz etkilediğini belirlemiştir.

Instagram fenomenlerinin güvenilirliği, çekiciliği ve uzmanlığının elektronik kulaktan kulağa pazarlama davranışı üzerine etkisini araştıran çalışmalar kısıtlıdır. Avcılar vd., (2018) Instagram reklamlarında sosyal medya fenomeni kullanımının elektronik kulaktan kulağa pazarlama davranışı üzerinde etkisinin olduğunu belirlemişlerdir. Saleem (2017) yaptığı araştırmada, elektronik kulaktan kulağa pazarlamanın güvenilirlik boyutları ile satın alma niyeti arasındaki ilişkiye aracılık ettiğini belirlemiştir. Loureiro ve Sarmento (2018) yaptığı araştırma sonucunda, kadın ve erkeklerin ünlülerin görüşlerinden etkilendiğini ancak elektronik kulaktan kulağa pazarlama faaliyetini en fazla erkeklerin yaptığını belirlemişlerdir. Yıldız ve Avcı (2019) ise instagram fenomenlerinin sözel ve görsel paylaşımlarının elektronik kulaktan kulağa pazarlama üzerinde etkisinin olduğunu belirlemişlerdir. Khan vd. (2015) tüketici satın alma niyetini etkileyen kulaktan kulağa pazarlama faktörlerini araştırmış ve sonuçta bu faktörleri güvenilirlik, kaynak benzerliği, kaynak cazibesi, sosyal ağ gücü, kaynak uzmanlığı ve bilgi kullanışlılığı olarak belirlemişlerdir.

Literatürde ayrıca güvenilirlik, uzmanlık ve çekicilik boyutlarının reklama yönelik tutum üzerine etkisini araştıran çalışmalar da yer almaktadır (Zhao, 2004; Van der Waltd vd., 2009; Said ve Napi, 2015; Samat vd., 2016; Erdoğmuş vd., 2016; Jespersen, 2017). Ayrıca ünlü kullanımının ve ünlülerin güvenilirlik boyutlarının marka güvenilirliği (Zvinte, 2017) marka hatırlanabilirliği (Palmieri, 2013), marka kişiliği (Dissanayake ve Weerasiri, 2017), marka sadakati (Audi vd., 2015) marka algısı ve farkındalığı (Elli, 2017) marka bilinci (Chan vd., 2017) ile ilişikilerini araştıran çalışmalar da mevcuttur. Ünlü kullanımı ve ünlünün güvenilirlik boyutları ile ile ilgili spor endüstrisinde yapılan çalışmalar ile (Pikas vd., 2012; Malik ve Sudhakar, 2014; Liu vd., 2016; Noushad vd., 2018), sosyal medyada paylaşılan mesajların güvenilirliğinin satın alma niyeti üzerine etkisini araştıran çalışmalar da (Pornpitakban, 2004; Zang, 2014; Braatz, 2017) literatürde yer almaktadır. Lord ve Putrevi (2009) ünlülerin güvenilirliğinin (çekicilik, uzmanlık, güvenilirlik) boyutları ile tüketici motivasyonu arasındaki ilişkiyi araştırmışlardır. Ayodeji O ve Jarrar (2018) ise müşterinin dikkatini çeken şeyin ünlüden ziyade ürünün kalitesi olduğunu belirlemişlerdir.

\section{Araştırmanın Metodolojisi}

\subsection{Araştırmanın Amacı}

Instagram, gerçek ve tüzel kişilerin yer aldığı sosyal medya platformlarından birisidir. Son dönemlerde kullanıcı sayısının artmasıyla beraber bu mecrada dijital dünyanın yeni 
ünlüleri olarak bilinen fenomenler ortaya çıkmıştır. Bu çalışmanın amacı da son dönemlerde popüler hale gelen Instagram fenomenlerinin güvenilirlik, uzmanlık ve çekicilik özelliklerinin, tüketicilerin marka tutumu, satın alma niyeti ve elektronik kulaktan kulağa pazarlama davranışı üzerindeki etkisinin olup olmadığını belirlemektir. $\mathrm{Bu}$ amaç doğrultusunda oluşturulan araştırma modeli ve hipotezler aşağıda yer almaktadır.

\subsection{Araştırma Modeli, Değişkenleri ve Hipotezleri}

Günümüzde Instagram fenomenleri ve ünlülerin reklam/tanıtım alanlarında marka savunucusu olarak kullanılması ile ilgili literatürün taranması ve incelenmesi neticesinde Ohanian'ın (1990) kaynak güvenilirliği modelinden uyarlanarak aşağıda yer alan araştırma modeli geliştirilmiştir. Aşağıdaki modele göre fenomenlerin güvenilirlikleri, güvenilirlik, uzmanlık ve çekicilik olmak üzere kaynak güvenilirliği modeli çerçevesinde 3 boyut olarak uyarlanmıştır. Konuyla ilgili kavramsal çerçeve ve literatür araştırması kısmında açıklandığı üzere, son yıllarda dijital dünyanın yeni ünlüleri olarak bilinen Instagram fenomenleri markaların dikkatini çekmektedir. Markalar tarafından ürün ve hizmetlerin tanıtım ve reklamlarında şarkıcı, aktör gibi ünlüler kullanılmak yerine takipçileri ile daha yakın iletişimde olan Instagram fenomenleri kullanılmaktadır. Dolayısı ile Instagram fenomenleri markalar ile tüketiciler arasında aracı görevini yerine getirmektedir. Kullanılan Instagram fenomenlerinin kaynak güvenilirliği modeli kapsamındaki güvenilirlik, uzmanlık ve çekicilik özelliklerinin, tüketici davranışları açısından Instagram fenomeninin yer aldığı markaya yönelik tutum, bu markaya yönelik satın alma niyeti ve bu marka ile ilgili olarak elektronik ortamdaki paylaşımlarını ifade eden elektronik kulaktan kulağa pazarlama üzerindeki etkisi araştırılmıştır. Fenomen güvenilirliği boyutları olarak uyarlanan güvenilirlik, uzmanlık ve çekicilik değişkenleri araştırmanın bağımsız değişkenlerini oluştururken, marka tutumu, satın alma niyeti ve elektronik kulaktan kulağa pazarlama davranışı değişkenleri ise araştırmanın bağımlı değişkenlerini oluşturmaktadır. Araştırmanın amacı ve belirlenen değişkenler doğrultusunda aşağıda yer alan araştırma hipotezleri geliştirilmiştir.

Şekil 1: Araştırma Modeli

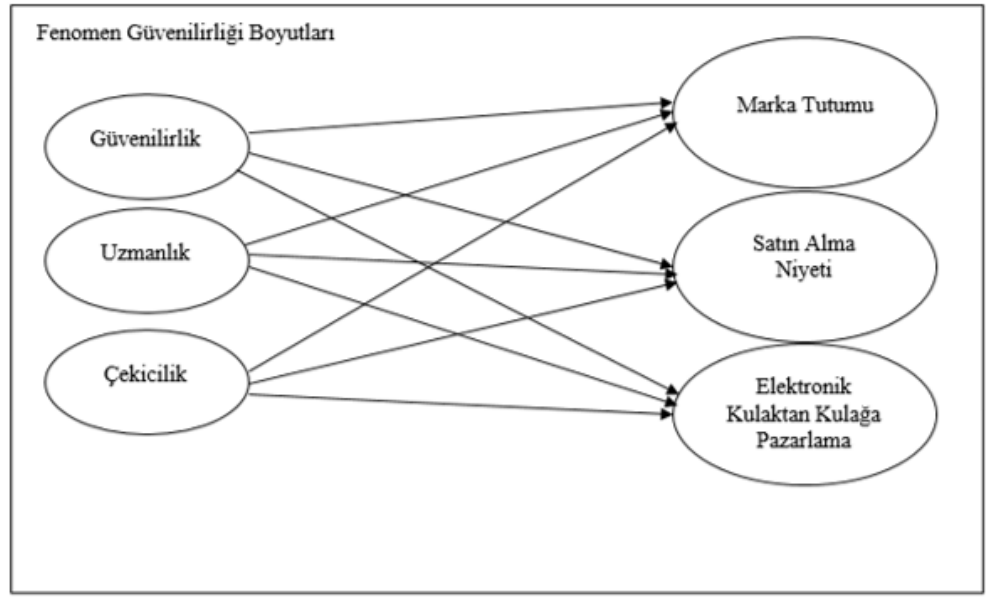


H1:Instagram fenomenlerinin güvenilirliklerinin marka tutumu üzerinde olumlu bir etkisi vardır.

H2:Instagram fenomenlerinin güvenilirliklerinin satın alma niyeti üzerinde olumlu bir etkisi vardır.

H3:Instagram fenomenlerinin güvenilirliklerinin elektronik kulaktan kulağa pazarlama davranışı üzerinde olumlu bir etkisi vardır.

H4:Instagram fenomenlerinin uzmanlıklarının marka tutumu üzerinde olumlu bir etkisi vardır.

H5:Instagram fenomenlerinin uzmanlıklarının satın alma niyeti üzerinde olumlu bir etkisi vardır.

H6:Instagram fenomenlerinin uzmanlıklarının elektronik kulaktan kulağa pazarlama davranışı üzerinde olumlu bir etkisi vardır.

H7:Instagram fenomenlerinin çekiciliklerinin marka tutumu üzerinde olumlu bir etkisi vardır.

H8:Instagram fenomenlerinin çekiciliklerinin satın alma niyeti üzerinde olumlu bir etkisi vardır.

H9:Instagram fenomenlerinin çekiciliklerinin elektronik kulaktan kulağa pazarlama davranışı üzerinde olumlu bir etkisi vardır.

\subsection{Araştırma Yöntemi}

Araştırma evrenini 18-38 yaş aralığı olarak bilinen $\mathrm{Y}$ jenerasyonunda yer alan Instagram kullanmış ve kullanmakta olan tüm tüketiciler oluşturmaktır. Ancak Instagram kullanan tüm tüketicilere zaman ve imkan kısıtları nedeniyle ulaşmak mümkün olmadığı için tesadüfi olmayan örnekleme yöntemlerinden kolayda örnekleme yöntemi kullanılmıştır. Ana kütleyi tam olarak temsil etmesi nedeniyle seçilen örneklem, farklı ekonomik, sosyal ve kültürel özellikteki tüketicilerden seçilmeye çalışılmıştır. Araştırma ile ilgili veriler hazırlanan soru formu (anket) ile toplanmıştır. Anket formu oluşturulurken konuyla ilgili literatürdeki çalışmalar incelenmiştir. Araştırmada yer alan fenomen güvenilirliği boyutlarındaki değişkenlerden güvenilirlik değişkeni 5 soru, uzmanlık değişkeni 5 soru, çekicilik değişkeni 5 soru (Ohanian, 1990), marka tutumu değişkeni 3 soru (Shaouf vd., 2016), satın alma niyeti 3 soru (Hwang vd., 2011) ve elektronik kulaktan kulağa pazarlama davranışı değişkeni 4 soru ile (Jin ve Pua, 2014) ölçülmeye çalışılmıştır. Hazırlanan anket formu 3 bölümden oluşmaktadır. İlk bölümde takip edilen Instagram fenomenleri ile ilgili 2 soru, ikinci bölümde bağımlı ve bağımsız değişkenlere ait 25 adet 5'li Likert tipi ölçeğine (Kesinlikle Katılmıyorum-Kesinlikle Katılıyorum) uygun sorular ve anketin son bölümünde katılımcıların demografik bilgilerini belirlemeye yönelik sorular yer almaktadır. Anket formu konuyla ilgili uzman kişilerin görüşleriyle düzenlenerek Instagram kullanan 20 katılımc1 üzerinde ön teste olarak test edilmiştir. Ön test sonrasında soru sayısında bir değişikliğe gidilmemiş, sadece yazım ve anlam olarak hatalı olan 2 soruda düzenleme yapılmıştır. En son haliyle düzenlenen anket formu 15.11.2018 ile 22.11.2018 tarihleri arasında Instagram 
kullanıcılarına online olarak uygulanmıştır. Veri toplama sürecinde 470 katılımcıya ulaşılmış ancak 28 anket eksik bilgi içerdiği için araştırmaya dahil edilmemiş ve 442 anket dikkate alınmıştır. Anketle toplanan 442 katılımcıya ait veriler SPSS 21 ve Yapısal Eşitlik Modeli (AMOS 24) ile analiz edilerek, analiz sonucunda elde edilen bulgu ve değerlendirmelere yer verilmiştir.

\section{Analiz ve Bulgular}

\subsection{Katılımcıların Demografik Özellikleri}

Araştırma sonucu elde edilen verilerin analizi neticesinde katılımcılarla ilgili demografik bilgileri gösteren değerler Tablo 1'de yer almaktadır.

Tablo 1: Katılımcıların Demografik Özellikleri

\begin{tabular}{|c|c|c|c|c|c|c|c|}
\hline & & Frekans & Yüzde & & & Frekans & Yüzde \\
\hline \multirow{3}{*}{ Cinsiyet } & Kadın & 215 & 48,6 & \multirow{3}{*}{$\begin{array}{l}\text { Medeni } \\
\text { Durum }\end{array}$} & Evli & 109 & 24,7 \\
\hline & Erkek & 227 & 51,4 & & Bekar & 333 & 75,3 \\
\hline & Toplam & 442 & 100 & & Toplam & 442 & 100 \\
\hline \multirow{6}{*}{ Yaş } & 18 ve alt1 & 77 & 17,4 & \multirow{7}{*}{$\begin{array}{l}\text { Öğrenim } \\
\text { Durumu }\end{array}$} & İlk Öğretim & 17 & 3,8 \\
\hline & $19-23$ aras1 & 164 & 37,1 & & Orta Öğretim & 95 & 21,5 \\
\hline & $24-28$ aras1 & 76 & 17,2 & & Önlisans & 112 & 25,3 \\
\hline & 29-33 aras1 & 79 & 17,9 & & Lisans & 153 & 34,6 \\
\hline & 34-38 aras1 & 46 & 10,4 & & Y. Lisans & 43 & 9,7 \\
\hline & Toplam & 442 & 100 & & Doktora & 22 & 5,0 \\
\hline \multirow{9}{*}{ Meslek } & $\begin{array}{l}\text { Serb. } \\
\text { Meslek }\end{array}$ & 27 & 6,1 & & Toplam & 442 & 100 \\
\hline & Memur & 64 & 14,5 & \multirow{8}{*}{$\begin{array}{l}\text { Gelir } \\
\text { Durumu }\end{array}$} & 1500 ve alt 1 & 175 & 39,6 \\
\hline & Esnaf & 13 & 2,9 & & $1501-3000$ & 89 & 20,1 \\
\hline & İşçi & 32 & 7,2 & & $3001-4500$ & 97 & 21,9 \\
\hline & Sözl. Per. & 23 & 5,2 & & $4501-6000$ & 49 & 11,1 \\
\hline & Ev Hanımı & 20 & 4,5 & & 6001 ve üstü & 32 & 7,2 \\
\hline & Öğrenci & 209 & 47,5 & & \multirow[t]{3}{*}{ Toplam } & \multirow[t]{3}{*}{442} & \multirow[t]{3}{*}{100} \\
\hline & Diğger & 54 & 12,0 & & & & \\
\hline & Toplam & 442 & 100 & & & & \\
\hline
\end{tabular}

Tablo 1'de görüldüğü üzere araştırmaya katılan katılımcıların; \%48,6'sı kadın ve \%51,4'ü erkek, büyük çoğunluğu ise bekar $(\% 75,3)^{\prime}$ dır. Katılımcıların yaklaşık olarak yarısı 19-25 yaş aralığında (\%37,1), eğitim durumu açısından \%48,5'i lisans, \%25,3'ü önlisans mezunu ve gelir seviyesi olarakta büyük çoğunluğu 1500 TL ve altındaki $(\% 39,6)$ öğrencilerden $(\% 47,5)$ oluşmaktadır.

\subsection{Faktör Analizi Sonuçları}

Araştırma kapsamında analize tabi tutulan güvenilirlik, uzmanlık, çekicilik, marka tutumu, satın alma niyeti ve elektronik kulaktan kulağa pazarlama davranışı ölçeklerinin seçilen örnekle uyum sağlayıp sağlamadığını belirlemek amacıyla faktör analizi kullanılmıştır. 
Tablo 2: Faktör Analizi Sonuçları

\begin{tabular}{|c|c|c|c|c|c|}
\hline Değişkenler & İfadeler & Fakt.Yükü & $\begin{array}{l}\text { Varyans } \\
\text { Yüzdesi }\end{array}$ & Özdeğeri & C. Alfa \\
\hline \multirow{5}{*}{$\begin{array}{l}\text { Güvenilirlik } \\
\text { Faktörü }\end{array}$} & GÜV1 & 0,881 & \multirow{5}{*}{73,661} & \multirow{5}{*}{3,683} & \multirow{5}{*}{0,905} \\
\hline & GÜV2 & 0,901 & & & \\
\hline & GÜV3 & 0,877 & & & \\
\hline & GÜV4 & 0,736 & & & \\
\hline & GÜV5 & 0,885 & & & \\
\hline \multirow{5}{*}{ Uzmanlık Faktörü } & UZMN1 & 0,874 & \multirow{5}{*}{75,979} & \multirow{5}{*}{3,799} & \multirow{5}{*}{0,919} \\
\hline & UZMN2 & 0,903 & & & \\
\hline & UZMN3 & 0,911 & & & \\
\hline & UZMN4 & 0,893 & & & \\
\hline & UZMN5 & 0,770 & & & \\
\hline \multirow{5}{*}{ Çekicilik Faktörü } & ÇEK1 & 0,767 & \multirow{5}{*}{66,112} & \multirow{5}{*}{3,306} & \multirow{5}{*}{0,872} \\
\hline & ÇEK2 & 0,743 & & & \\
\hline & ÇEK3 & 0,841 & & & \\
\hline & ÇEK4 & 0,859 & & & \\
\hline & ÇEK5 & 0,849 & & & \\
\hline \multirow{3}{*}{ Marka Tutumu } & MT1 & 0,930 & \multirow{3}{*}{87,712} & \multirow{3}{*}{2,631} & \multirow{3}{*}{0,930} \\
\hline & MT2 & 0,946 & & & \\
\hline & MT3 & 0,934 & & & \\
\hline \multirow{3}{*}{ Satın Alma Niyeti } & SAN1 & 0,903 & \multirow{3}{*}{81,611} & \multirow{3}{*}{2,448} & \multirow{3}{*}{0,887} \\
\hline & SAN2 & 0,929 & & & \\
\hline & SAN3 & 0,878 & & & \\
\hline \multirow{4}{*}{$\begin{array}{l}\text { Elektronik } \\
\text { Kulaktan Kulağa } \\
\text { Pazarlama }\end{array}$} & EWOMM1 & 0,817 & \multirow{4}{*}{72,017} & \multirow{4}{*}{2,881} & \multirow{4}{*}{0,869} \\
\hline & EWOMM2 & 0,854 & & & \\
\hline & EWOMM3 & 0,867 & & & \\
\hline & EWOMM4 & 0,856 & & & \\
\hline
\end{tabular}

Faktör analizi sonucunda güvenilirlik ölçeğinin alpha katsayısı 0,905, uzmanlık ölçeğinin alpha katsayısı 0,919, çekicilik ölçeğinin alpha katsayısı 0,872, marka tutumu ölçeğinin alpha katsayısı 0,930, satın alma niyeti ölçeğinin alpha katsayısı 0,887, elektronik kulaktan kulağa pazarlama davranışı ölçeğinin alpha katsayısı 0,869 olarak belirlenmiştir. Faktör yükleri 0,50 ve üstünde olan değişkenler dikkate alınmıştır (Turanlı vd., 2012: 49). Ayrıca analiz sonucunda örneklem yeterlilik ölçütü açısından güvenilirlik ölçeği KMO 0,877, Barlett Küresellik testi: 1518,174 ve p<0,000, uzmanlık ölçeği KMO (Kaiser-Meyer-Olkin) 0,876, Barlett: 1676,720 ve p<0,000, çekicilik ölçeği KMO: 0,841, Barlett: 1103,646 ve p<0,000, marka tutumu ölçeği KMO: 0,762, Barlett: 1069,718 ve p<0,000, satın alma niyeti ölçeği KMO: 0,727, Barlett: 767,590 ve p<0,000, elektronik kulaktan kulağa pazarlama davranışı ölçeği KMO: 0,715, Barlett: 1065,273 ve p<0,000 olarak belirlenmiştir. Elde edilen güvenilirlik, uzmanlık, çekicilik, marka tutumu, satın alma niyeti ve elektronik kulaktan kulağa pazarlama değişkenleri ile ilgili faktör yükleri, varyans yüzdeleri ve öz değerleri Tablo 2'de gösterilmektedir

\subsection{Araştırma Modelinin Yapısal Eşitlik Uygunluğu}

Araştırma modelinin uygun olup olmadığı ile ilgili değerlendirmede ki-kare istatistiği RMSEA (Ortalama hata karekök yaklaşımı) ve GFI (Uyum iyiliği indeksi) kullanılmıştır. 
RMSEA değeri için 0.05 'e eşit ve daha küçük değerlerin mükemmel, 0.08 ve altındaki değerlerin kabul edilebilir, 0.10 'dan büyük değerlerde kötü uyuma karşılık gelmektedir. GFI değeri için ise 0.95 ve üzeri mükemmel uyuma, 0.90 ve 0.94 arası kabul edilebilir uyuma karşılık gelmektedir (Şimşek 2007: 48). Ancak literatürde yer alan farklı araştırmalarda Yapısal Eşitlik Modeli ile yapılan analiz sonuçlarının kabul edilebilirlik uyum endekslerine göre GFI değerinin 0.90'ın üzerinde kabul edilebilir veri olarak ifade edilmiştir (Gautam ve Kumar 2011: 14).

Yapısal Eşitlik Modeli analizi sonucunda Tablo 3'deki değerler, oluşturulan modelin uyum değerlerinin kabul edilebilir sınırlar içerisinde yer aldığını ve modelin yapısal olarak uygun olduğuna ilişkin yeterli kanıtları sağlamaktadır.

Tablo 3: Yapısal Eşitlik Değerlendirme Tablosu

\begin{tabular}{lll}
\hline Uyum İndeksleri & Önerilen & Model \\
\hline X2 & - & 539,522 \\
df & - & 252 \\
X2/df & $\leq 3$ & 2,141 \\
GFI & $\geq 90$ & 0,911 \\
CFI & $\geq 90$ & 0,967 \\
RMSA & $\leq 0,05$ & 0,051 \\
NFI & $\geq 90$ & 0,939 \\
RFI & $\geq 90$ & 0,928 \\
IFI & $\geq 90$ & 0,967 \\
TLI & $\geq 90$ & 0,960 \\
\hline
\end{tabular}

Yapısal Eşitlik Modeli analizi neticesinde ortaya çıkan sonuçlar araştırma modelinin kabul edilebilir ve iyi seviyede uyum indekslerine sahip olduğunu göstermektedir. Analiz sonucunda NFI: 0,939, RFI: 0,928, IFI: 0,967 ve TLI: 0,960 olarak bulunmuştur. Yapılan araştırma sonuçlarına göre araştırma modeli kapsamındaki ilişkiler anlamlı çıkmıştır. Yapısal modelin hipotez testi sonuçları aşă̆ıdaki tabloda gösterilmiştir.

Tablo 4: Hipotez Tablosu

\begin{tabular}{llllll}
\hline & Hipotezler & $\boldsymbol{\beta}$ & S.E. & $\mathbf{P}$ & Durum \\
\hline H1 & GÜV $\rightarrow$ MT &, 310 &, 079 &, $001^{*}$ & Kabul \\
H2 & GÜV $\rightarrow$ SAN &, 415 &, 090 &, $001^{*}$ & Kabul \\
H3 & GÜV $\rightarrow$ EKKP &, 340 &, 075 &, $001^{*}$ & Kabul \\
H4 & UZMN $\rightarrow$ MT &, 039 &, 073 &, 591 & Kabul edilmedi \\
H5 & UZMN $\rightarrow$ SAN &, 074 &, 083 &, 372 & Kabul edilmedi \\
H6 & UZMN $\rightarrow$ EKKP &, 096 &, 069 &, 163 & Kabul edilmedi \\
H7 & ÇEK $\rightarrow$ MT &, 362 &, 051 &, $001^{*}$ & Kabul \\
H8 & ÇEK $\rightarrow$ SAN &, 375 &, 057 &, $001^{*}$ & Kabul \\
H9 & ÇEK $\rightarrow$ EKKP &, 333 &, 048 &, $001^{*}$ & Kabul \\
\hline
\end{tabular}

${ }^{*} \mathrm{p}<0,01,{ }^{* *} \mathrm{p}<0,05,{ }^{* * *} \mathrm{p}<0,10$

Araştırmanın hipotez testi sonuçlarına incelendiğinde $\mathrm{p}<0,01$ anlamlılık düzeyinde yer alan H1, H2, H3, H7, H8 ve H9 hipotezlerinin istatistiksel olarak anlaml fark olduğu ve desteklendiği, H4 hipotezinin 0,591, H5 hipotezinin 0,372 ve H6 hipotezinin 0,163 p değeri ile 0,10 ' dan büyük olduğu için istatistiksel olarak anlamlı fark olmadığı ve dolayısı ile bu hipotezlerin desteklenmediği görülmektedir. 


\section{Sonuç ve Öneriler}

Sosyal medya araçlarının popülerliğinin artması ve giderek tüketicilerin hayatında yer etmesi işletmelerin de dikkati çekmiştir. Bu amaçla mevcut ve potansiyel müşterilerin dikkatini çekmek ve onlarla iletişim sağlamak amacıyla Facebook, Instagram ve Twitter gibi sosyal medya araçlarını kullanmaya başlamışlardır. Özellikle Instagram’ın Dünya'da ve Türkiye'de kullanıcı sayısı açısından diğer araçlardan önde olması işletmelerin dikkatini çekmiş ve pazarlama faaliyetlerini Instagram üzerinden gerçekleştirmeye başlamışlardır. İşletmelerin kurumsal Instagram hesaplarının yanısıra Instagram'da binlerce hatta milyonlarca takipçilere sahip olan ve fenomen olarak adlandırılan yeni nesil ünlüler, bu pazarlama faaliyetlerinde ürün ve hizmet savunucusu olarak kullanılmaya başlanmıştır. Bu noktada araştırmanın temel amacı Instagram fenomenlerinin güvenilirlik, uzmanlık ve çekicilik özelliklerinin, onlara takip eden takipçilerin marka tutumu, satın alma niyeti ve elektronik kulaktan kulağa pazarlama davranışı üzerinde etkisinin olup olmadığını belirlemektir. Bu amaçla online olarak Instagram kullanan tüketiciler üzerinde yapılan araştırma neticesinde elde edilen verilerin analizi sonucunda Instagram fenomenlerinin güvenilirlik ve çekicilik özelliklerinin marka tutumu, satın alma niyeti ve elektronik kulaktan kulağa pazarlama üzerinde olumlu etkilerinin olduğu, uzmanlık özelliğinin ise anlamlı bir etkisinin olmadı̆̆ belirlenmiştir.

Araştırma sonuçlarına bakıldığında Instagram fenomenlerinin çekicilik özelliğinin marka tutumu, satın alma niyeti ve elektronik kulaktan kulağa pazarlama üzerinde olumlu etkisinin olduğu belirlenmiştir. Diğer bir deyişle, Instagram fenomenini çekici olarak algılayan takipçilerin, fenomenin herhangi bir marka ile ilgili yaptığ paylaşımlar sonucunda, bu markaya karşı olum tutum geliştirdikleri, bu markayı satın almaya niyetli oldukları ve bu marka ile ilgili olumlu düşünceleri elektronik ortamda arkadaşları ile paylaştıkları söylenebilir. Dolayısı ile bu sonuçlar doğrultusunda $H 7, \mathrm{H} 8$ ve H9 hipotezleri desteklenmiştir. Bu araştırma, çekiciliğin marka tutumu (Stanley vd., 2009; Amos vd., 2008; Mumnuka, 2016) satın alma niyeti (Ohanian, 1990; Renton, 2006; Smink, 2013; Shelton ve Chiliya, 2014; Sertoğlu vd., 2014) üzerinde olumlu etkisinin olduğu sonucuna ulaşan literatürdeki diğer araştırmaları da desteklemektedir. Önceki çalışmalarda Instagram fenomeninin çekiciliğinin elektronik kulaktan kulağa pazarlama üzerinde etkisinin olup olmadığını araştıran çalışma olmadığ1 için bu araştırma sonucu elde edilen sonucun literatüre katkı sağlayacağı düşünülmektedir. Ancak Saleem (2017) elektronik kulaktan kulağa pazarlamanın, çekicilik ve güvenilirlik boyutu ile satın alma niyeti arasında aracılık ettiğini belirlemiştir. Ayrıca Avcılar vd. (2018), Instagram fenomeninin reklamlarda kullanılmasının elektronik kulaktan kulağa pazarlama üzerinde etkisinin olduğunu belirlemişlerdir. Instagram fenomenlerinin güvenilirliklerinin marka tutumu, satın alma niyeti ve elektronik kulaktan kulağa pazarlama üzerinde olumlu etkisinin olduğu araştırma sonucunda bulunan bir diğer sonuçtur. Dolayısı ile herhangi bir fenomeni takip eden takipçiler, ilgili fenomeni güvenilir olarak algıladıklarında, fenomenin reklamını yaptığı markaya karşı olumlu bir tutum geliştirmekte, bu markayı satın almaya niyetli olmakta ve bu markaya yönelik düşüncelerini elektronik platformlarda paylaşmaktadır. Bu sonuçlar H1, H2 ve H3 hipotezlerinin desteklendiğini göstermektedir. Literatürde incelendiğinde bu araştırma, 
güvenilirlik boyutunun satın alma niyeti üzerinde (Ohanian, 1990; Renton, 2006) ve marka tutumu üzerinde (Renton, 2006; Amelina ve Zhu, 2016; Wang vd., 2017) etkisinin olduğu sonucuna ulaşan araştırmaları destekler niteliktedir. Elektronik kulaktan kulağa pazarlama ilgili olarak ise Wu ve Wang (2011), elektronik kulaktan kulağa pazarlamanın güvenilirlik ile marka tutumu arasında aracılık ettiğini belirlemişlerdir. Instagram fenomenlerinin uzmanlık boyutunun marka tutumu, satın alma niyeti ve elektronik kulaktan kulağa pazarlama davranışı üzerinde bir etkisinin olmadığı araştırma sonucunda bulunan bir diğer sonuçtur. Bu sonuca göre Instagram fenomeninin takipçileri tarafından uzman olarak algılanıp algılanmamasının, tüketicilerin fenomen tarafından paylaşımı yapılan markaya yönelik tutum, satın alma niyeti ve elektronik kulaktan kulağa pazarlama davranışı göstermesini etkilememektedir. Dolayısı ile H4, H5 ve H6 hipotezleri desteklenmemiştir. Literatürde Instagram fenomeninin uzmanlık boyutunun satın alma niyeti (Khan vd., 2016) ve marka tutumu (Renton, 2006; Amelina ve Zhu, 2016; Wang vd., 2017) üzerinde etkisinin olmadığı sonucuna ulaşan araştırmalar yer almaktadır. Dolayısı ile elde edilen bu sonuç literatürdeki benzer çalışmalarla aynı sonucu paylaşmaktadır.

Araştırma sonuçları genel olarak değerlendiğinde markalar için önemli bir platform olan Instagram'daki fenomenlerin tüketiciler üzerinde etkilerinin olduğu yadsınamaz bir gerçektedir. Fenomen güvenilirliği olarak ifade edilen güvenilirlik, çekicilik ve uzmanlık boyutlarından oluşan modelin, yapılan analizler sonucunda güvenilirlik ve çekicilik boyutlarının daha etkili olduğu belirlenmiştir. Araştırma sonucu elde edilen bu sonuçların literatüre katkısı sağlayacağı söylenebilir. Ayrıca araştırmanın Instagram fenomenleri ile ilgili yapılan çalışmalardan farklı olarak, güvenilirlik, çekicilik ve uzmanlık kapsamında değerlendirildiğinde ulusal kapsamda yapılan ilk çalışmalardan biri olması araştırmanın özgünlügüüne katkı sağlamaktadır. Bu sonuçlar doğrultusunda pazarlama faaliyetlerinde Instagram fenomenlerini kullanacak olan marka ve işletmelere takipçileri tarafından genellikle güvenilir ve çekici olarak algılanan fenomenleri kullanmaları önerilebilir. Konu ile ilgili gelecekteki araştırmacılara ise fenomen güvenilirliği boyutu olarak uyarlanan bu üç boyut ile takipçi sayısı açısından fenomen türleri arasındaki ilişkiyi ve bu üç boyut üzerinde fenomenlerin demografik özelliklerinin etkisini araştırmaları önerilebilir.

\section{Kaynakça}

Ahmed, N., Farooq, O. and Iqbal, J. (2014). Credibility of Celebrity Endorsement and Buying Intentions an Evidence from Students of Islamabad, Pakistan. International Letters of Social and Humanistic Sciences Online, 20(9), 1-13.

Alboqami, H., Al-Karaghouli, W., Baeshen, Y., Erkan, I., Evans, C. and Ghoneim, A. (2015). Electronic Word of Mouth in Social Media: The Common Characteristics of Retweeted and Favourited Marketer Generated Content Posted on Twitter. International Journal of Internet Marketing and Advertising, 9(4), 338-358. 
Amelina, D. and Zhu, Y.Q. (2016). Investigating Effectiveness of Source Credibility Elements on Social Commerce Endorsement: The Case of Instagram in Indonesia. Pacific Asia Conference on Information Systems, Chiayi, 232.

Amos, C., Holmes, G. and Strutton, D. (2008). Exploring the Relationship between Celebrity Endorser Effects and Advertising Effectiveness: A Quantitative Synthesis of Effect Size. International Journal of Advertising, 27(2), 209-234.

Anghel, C. (2009). The Effect of Celebrity Endorsements on Gift-Giving Purchases: An Application of the Elaboration Likelihood Model, (Yayımlanmamış Yüksek Lisans Tezi), University of South Florida, USA.

Apeyoje, A. (2013). Influence of Celebrity Endorsement of Advertisement on Students' Purchase Intention. Mass Communication and Journalism, 3(3), 3-10.

Arndt, J. (1967). Role of Product-Related Conversations in the Diffusion of A New Product. Journal of Marketing Research, 4(3), 291-295.

Audi, M., Masri, R.A. and Ghazzawi, K. (2015). The Effect of Celebrity Endorsement on Creating Brand Loyalty: An Application on the Lebanese Cosmetic Sector's Demand. International Journal of Business Management and Economic Research (IJBMER), 6(5), 273-287.

Avcılar, M.Y., Demirgüneş, B.K. ve Açar, M.F. (2018). Instagram Reklamlarında Ürün Destekçisi Olarak Sosyal Medya Fenomeni Kullanımının Reklama Yönelik Tutum ve E-Wom Niyetine Etkilerinin İncelenmesi. Pazarlama ve Pazarlama Araştırmaları Dergisi, 21, 1-27.

Ayodeji O, A. and Jarrar, Y. (2018). Celebrity Endorsement and Its Impact on Consumer Perception: A Study of Globacom Nigeria Limited. International Journal of Economics, Business and Management Research, 2(3), 28-46.

Aziz, S., Ghani, U. and Niazi, A. (2013). Impact of Celebrity Credibility on Advertising Effectiveness. Pakistan Journal of Commerce and Social Sciences, $7(1), 107-127$.

Baldinger, A. L. and Rubinson, J. (1996). Brand Loyalty: The Link Between Attitude and Behavior. Journal of Advertising Research, 36(6), 22-35.

Belch, G. E. and Belch, M. A. (2004). Advertising and Promotion: An Integrated Marketing Communications Perspective. Boston: McGraw-Hill.

Biehal, D., Gabriel, C. and Stephens, E. (1992). Attitude Toward the Ad and Brand Choicei. Journal of Advertising, 21(3), 19-37.

Bozbay Z., Karami A. and Arghashi V. (2018). The Relationship between Brand Love and Brand Attitude. 2nd International Conference on Management and Business, Tebriz, Iran, 8-9 Mayıs, 1-10.

Braatz, L.A. (2017). Influencer Marketing on Instagram Consumer Responses Towards Promotional Posts: The Effects of Message Sidedness and Product Depiction, (Yayımlanmamış Yükseklisans Tezi), University of Twente, Netherland.

Bush, A. J., Martin, C. A. and Bush, V. D. (2004). Sports Celebrity Influence on The Behavior of Generation Y. Journal of Advertising Research, 44(1), 108-118. 
Carvalho, A.F.E.M. (2012). The Effects of Celebrity Endorsement on Consumers Purchasing Intentions, (Yayımlanmamış Yükseklisans Tezi), ISCTE Business School, Portugal.

Chan, H.C.C., Mazodier, M. and Remaud, H. (2016). The Impact of Celebrity Endorsement on Wine Brands' Likeability and Purchase Intention: A Chinese Perspective. 9th Academy of Wine Business Research Conference, 2016.

Chan, K., Ng, Y. and Luk, E. (2013). Impact of Celebrity Endorsement in Advertising on Brand Image Among Chinese Adolescents. Young Consumers, 14(2), 167-179.

Chaovalit, P. (2014). Factors Influencing Cosmetics Purchase Intention in Thailand: A Study on The Relationship of Credibility and Reputation with The Persuasive Capabilities of Beauty Bloggers. AU-GSB e-Journal, 7(1), 34-42.

Charbonneau, J. and Garland, R. (2006). The Use of Celebrity Athletes As Endorsers: Views of the New Zealand General Public. International Journal of Sports Marketing and Sponsorship, 7(4), 31-38.

Chekima, F.Z., Wafa, S.A.W.S.K. and Sulong, R.S. (2018). The Impact of Celebrity Credibility on Purchase Intention of Cosmetic Products: The Moderating Role of Ethnocentrism. Asian Journal of Economics, Business and Accounting, 7(1), 1-10.

Chu, S. C. and Kim, Y. (2011). Determinants of Consumer Engagement in Electronic Word-of-Mouth (EWOM) in Social Networking Sites. International Journal of Advertising, 30(1), 47-75.

Çinkay, B. (2017). Sosyal Medya Pazarlamasında Ünlü Onaylayanların Tüketici Algısı ve Satın Alma Niyeti Üzerine Etkisi, (Yayımlanmamış Doktora Tezi) Kahramanmaraş Sütçü İmam Üniversitesi Sosyal Bilimler Enstitüsü İşletme Ana Bilim Dalı, Kahramanmaraş.

Dangl, V. (2017). Social Media Influencer Marketing; An Empirical Study on Brand Sponsorships and the Effects on Credibility of Social Media Influencers in the Fitness Industry, (Yayımlanmamış Yükseklisans Tezi), Johannes Kepler University Linz, Austria.

DeShields, O.W. (1992). The Relationship Between Spokesperson Credibility and Purchase Intentions : A Proposed Theory and Experimental Evaluation. FIU Electronic Theses and Dissertations. 2779.

Dissanayake D.M.R. and Weerasiri R.A.S. (2017). The Impact of Perceived Effectiveness of Celebrity Endorsement on Perceived Brand Personality. J Account Mark, 6(3), 1-9.

Dissanayake, D.M.R. and Ismail, N. (2015). Relationship between Celebrity Endorsement and Brand Attitude: With Reference to Financial Services Sector Brands in Sri Lanka. 6th International Conference on Business $\mathcal{E}$ Information ICBI - 2015, Faculty of Commerce and Management Studies, University of Kelaniya, Sri Lanka, 472-487.

Djafarova, E. and Rushworth, C. (2017). Exploring the Credibility of Online Celebrities' Instagram Profiles in Influencing The Purchase Decisions of Young Female Users. Computers in Human Behavior, 68, 1-7. 
Doss, S. (2011). The Transference of Brand Attitude: The Effect on the Celebrity Endorser. Journal of Management and Marketing Research. 7(1), 1-11.

Eisend, M. and Langner, T. (2010). Immediate and Delayed Advertising Effects of Celebrity Endorsers' Attractiveness and Expertise. International Journal of Advertising, 29(4), 527-546.

Elli, D.M. (2017). The Phenomenon and Rise of Influencer Marketing and How It Affects Customer Opinion and Helps or Damages Brands, (Yayımlanmamış Yükseklisans Tezi), School of Science \& Technology (SST), USA.

Emma, N. ve Matilde, P. (2017). Title of Thesis Celebrities of Instagram - What Type of Content Influences Followers' Purchase Intentions and Engagement Rate?, (Yayımlanmamış Yükseklisans Tezi), Aalto University, Finland.

Erdoğan, B.Z. (1999). Celebrity Endorsement: A Literature Review. Journal of Marketing Management, 41(3), 291-314.

Erdoğmuş, İ.E., Laka, H.S. and Çiçek, M. (2016). Attractive or Credible Celebrities: Who Endorses Green Products Better?. Procedia - Social and Behavioral Sciences, 235, 587-594.

Erkan, I. and Evans, C. (2014). The Impacts of Electronic Word of Mouth in Social Media on Consumers' Purchase Intentions. Proceedings of the International Conference on Digital Marketing (ICODM2014), Colombo, Sri Lanka, 9-14.

Ewers, N.L. (2017). Influencer Marketing on Instagram An Analysis of the Effects of Sponsorship Disclosure, Product Placement, Type of Influencer and Their Interplay on Consumer Responses, (Unpublished Master Thesis), University of Twente, Netherland.

Freeman, K. S. and Chen, C.C. (2015). Wither The Impact of Celebrity Endorsement, International Conference on Communications, Media, Technology and Design. Dubai, UAE, 16-18 May 2015.

Friedman, H. H., Termini, S. and Washington, R. (1976). The Effectiveness of Advertisements Utilizing Four Types of Endorsers. Journal of Advertising, 5 (3), 22-24.

Gaied A.M. and Rached, K.S.B. (2010). The Persuasive Effectiveness of Famous and Non Famous Endorsers in Advertising. IBIMA Publishing, IBIMA Business Review, http://www.ibimapublishing.com/journals/IBIMABR/ibimabr.html.

Garifova, L. F. (2016). Realization of Small Businesses Economic Interests on Instagram. Journal of Economics and Economic Education Research, 17, 133-139.

Garland, R. and Ferkins, L. (2003). Evaluating New Zealand Sports Stars As Celebrity Endorsers: Intriguing Results. Proceedings of ANZMAC Conference, University of South Australia, Adelaide (December), CD ROM, 122-129.

Gautam, V. and Kumar, M. (2011). An Empirical Investigation of Factors Determining The Consumers' Choice of Mobile Service Providers. İşletme Araştırmaları Dergisi, 3 (4), 3-17.

Kotler, P. (2005). A'dan Z'ye Pazarlama, 9. Baskı, MediaCat Kitapları.

Gruber, A. (1970). Purchase Intent and Purchase Probability. Journal of Advertising Research, 10(1), 23-27. 
Hamid, N.A. and Fern, C.Y.A. (2016). Siti Nurhaliza and Purchase Intention Among University Students in Malaysia. Indian Journal Of Arts, 6(17), 48-68.

Hennig-Thurau, T., Gwinner, K.P., Walsh, G. and Gremler, D.D. (2004). Electronic Word-Of Mouth Via Consumer-Opinion Platforms: What Motivates Consumers to Articulate Themselves on the Internet?'. Journal of Interactive Marketing, 18(1),38-52.

Hovland, C. I., Janis, I. L. and Kelley, H. H. (1953). Communication and Persuasion, Psychological Studies Of Opinion Change. New Haven: Yale University Press.

Ibok and Ibok,N. (2013). Factors Determining the Effectiveness of Celebrity Endorsed Advertisements: The Case of Nigerian Telecommunication Industry. American Journal of Business and Management, 2(3), 233-238.

Jespersen, C.F. (2017). Celebrity Endorser's Credibility: Effect on Consumers' Attitude Toward Advertisement Factors Influencing Vloggers Credibility Among Viewers and Their Relation with Attitude Toward Advertisement, (Yayımlanmamış Yükseklisans Tezi), Luleå University of Technology, Sweden.

Khalid, M. and Siddiqui, D.A. (2018). Impact of celebrity endorsement on consumer buying behavior towards beauty soap in Karachi city. https://mpra.ub.unimuenchen.de/89161/.

Khan, K. S., Rukhsar, A. and Shoaib, M. (2016). Influence of Celebrity Endorsement on Consumer Purchase Intention. Journal of Business and Management, 18(1), 6-9.

Khan, S.A., Ramzan, N., Shoaib, M. and Mohyuddin, A. (2015). Impact Of Word Of Mouth On Consumer Purchase Intention. Sci.Int.(Lahore), 27(1), 479-482.

Kim, J-W., Choi, J., Qualls, W. and Han, K. (2008). It Takes A Market Place Community to Raise Brand Commitment: The Role of Online Communities. Journal of Marketing Management, 24, 409-431.

Kim, S. and Choi, S. M. (2012). Credibility Cues in Online Shopping: An Examination of Corporate Credibility, Retailer Reputation and Product Review Credibility. International Journal of Internet Marketing and Advertising, 7(3), 217-236.

Ko, E., Kim, K.H. and Zhang, H. (2008). A Cross Cultural Study of Antecedents of Purchase Intention for Sports Shoes In Korea and China. Journal of Global Academy of Marketing Science, 18(1), 157-177.

Lisıchkova, N. and Othman, Z. (2017). The Impact Of Influencers On Online Purchase Intent, School of Business, Society and Engineering, (Yayımlanmamış Yükseklisans Tezi), Mälardalen University, Sweden.

Ling, K.C., Lau, T.C. and Tan, H.P. (2010). The Effects of Shopping Orientations, Online Trust, Prior Online Purchase Experience Toward Customers' Online Purchase Intention. International Business Research, 3 (3), 63-75.

Liu, L., Parganas, P., Chadwick, S. and Anagnostopoulos, C. (2016). Sports Celebrity Endorsements of Luxury Brands: The Case of Chinese Consumers. International Journal of Sport Management Recreation E Tourism, 25, 45-68. 
Lord, K. and Putrevi, S. (2009). The Effects of Informational and Transformational Motivations on Responses Toward Celebrity Endorsements. Advances in Consumer Research, 8, 291-293.

Loureiro, S. M. C. and Sarmento, E. M. (2018). The Role of Word-of-Mouth and Celebrity Endorsement in Online Consumer-Brand Relationship: The Context Of Instagram. In 2018 Global Fashion Management Conference, 11191129, Tokyo.

Malik, A. and Sudhakar, B.D. (2014). Brand Positioning Through Celebrity Endorsement - A Review Contribution to Brand Literature. International Review of Management and Marketing, 4(4), 259-275.

Malik, H.M. and Qureshi, M.M. (2016). The Impact of Celebrity Endorsement on Consumer Buying Behavior. Journal of Marketing and Consumer Research, 126, 112-126.

Messiaen, J. (2017). Influencer Marketıng How The Popularity Threshold Of Instagram Influencers Impacts Consumer Behaviour: The Moderating Role Of Purchase Involvement, (Yayımlanmamış Yükseklisans Tezi), Gent University, Belgium.

Mitchell, Andrew A. and Jerry C. Olson, (1981). Are Product a Beliefs the Only Mediator of Advertising Effects on Brand Attitud., Journal of Marketing Research, 18 (August), 318-332.

Munnuka, J., Uusitalo, O. and Toivonen, H. (2016). Credibility of A Peer Endorser and Advertising Effectiveness. Journal of Consumer Marketing, 33(3), 182-192.

Nhung, N.P., Sarinya, P. and Claire, T.X.H. (2011). Effectiveness of Consumer Endorser in Social Media Advertisement Impact on Consumers Attitudes and Behaviors, (Yayımlanmamış Yükseklisans Tezi), Lund University, Sweden.

Noushad P.M., Sajikumar, K.B. and Vineeth, K.M. (2018). Comparative Study of Influence of Celebrity Endorsements by Film Stars and Sportspersons with Special Reference to FMCG Products. Research Review International Journal of Multidisciplinary, 3(8), 185-190.

Ohanian, R (1990). Construction and Validation of a Scale to Measure Celebrity Endorser's Perceived Expertise, Trustworthiness and Attractiveness. Journal of Advertising, 19(3): 39-52.

Palmieri, L. (2013). Celebrity Endorsements in Print and Twitter: Comparing Brand Name Memorability and Credibility, (Yayımlanmamış Yükseklisans Tezi), The Rochester Institute of Technology, USA.

Park, D. and Kim, S. (2008). The Effects of Consumer Knowledge on Message Processing of Electronic Word-Of-Mouth Via Online Consumer Reviews. Electronic Commerce Research and Applications, 7(4), 399-410.

Pikas, B., Schied, R. and Pikas, A. (2012). Assessing the Qualities of Athlete Endorsers: A Study of Consumer Preferences for the 3 Qualities of Sports Endorsers Attractiveness, Trustworthiness, Expertise. Journal of Marketing Development and Competitiveness, 6(3), 42-55. 
Pornpitakpan, C. (2004). The Effect of Celebrity Endorsers' Perceived Credibility on Product Purchase Intention. Journal of International Consumer Marketing, 16(2), 55-74.

Pritzen, P. (2012). Point, Set, Match: Examining The Impact Of Athlete Endorser Familiarity And Endorser/Product Congruency On Consumer Attitude, Purchase Intentions And Percieved Endorser Credibility, (Yayımlanmamış Yükseklisans Tezi), University of Missouri, USA.

Rachbini, W. (2018). The Influence of Celebrity Endorsements on Purchase Intention (A Study on VIVO V7). IOSR Journal of Business and Management, 20(8), 59-66.

Rebelo, M. (2017). How Influencers' Credibility on Instagram is Perceived by Consumers and Its Impact on Purchase Intention, (Yayımlanmamış Yükseklisans Tezi), MSc. Universidade Católica Portuguesa, Portugal.

Renton, K. (2006). The Relationship of Celebrity Advertisements to Consumer Attitudes and Purchases Intentions, (Yayımlanmamış Yükseklisans Tezi), The Florida State University, USA.

Said, N.P.B.M. and Napi, W.N.B.W. (2015). Celebrity And Non-Celebrity Endorsement Effectiveness On Consumers' Attitude Towards Advertisement. International Academic Research Journal of Business and Technology, 1(2), 51-57.

Saleem, F. (2017). The Impact of Celebrity Endorsement on Brand Affection and Purchase Intention: The Mediating Role of Word of Mouth. The Lahore Journal of Business, 5(2), 45-66.

Samat, M.F., Ramlee, N.A.Z., Abu Bakar, H., Annual, N. and Rasid, M.F.R.M. (2016). Endorser Credibility and its Influence on The Purchase Intention of Social Networking Sites Consumer: A Mediating Role of Attitudes Towards SNS Advertising. International Journal of Management and Applied Science (IJMAS), 2(12), 50-56.

Schapers, R. (2013). The Rise of Influencer Marketing A Quantitative Study That Addresses Influencer Marketing on Instagram Together with the Impact of Sponsorship Disclosure, Colour Characteristics, Brand Involvement and Gender, (Yayımlanmamış Yükseklisans Tezi), Amsterdam Business School, Netherland.

Seiler, R. and Kucza, G. (2017). Source Credibility Model, Source Attractıveness Model And Match-Up Hypothesis - An Integrated Model. Journal of International Scientific Publications: Economy and Business, 11(1), 1-15.

Sertoğlu, A.E., Çatlı, Ö. and Korkmaz, S. (2014). Examining the Effect of Endorser Credibility on the Consumers' Buying Intentions: An Empirical Study in Turkey. International Review of Management and Marketing, 4(1), 66-77.

Sheinin, D.A.,Varki S. and Ashley, C. (2011). The Differential Effect of Ad Novelty and Message Usefulness on Brand Judgments. Journal of Advertising, 40(3), 517. 
Shelton, J. and Chiliya, N. (2014). Brand Endorsements: An Exploratory Study into the Effectiveness of Using Video Game Characters as Brand Endorsers. Mediterranean Journal of Social Sciences, 5(14), 260-275.

Shimp, T. (1981). Attitude Toward The Ad as a Mediator of Consumer Brand Choice. Journal of Advertising Research, 10(2), 9-15.

Smink, H.A. (2013). Combining Source Trustworthiness With Message Credibility. Are You Being Persuaded?, (Yayımlanmamış Yükseklisans Tezi), University Of Twente, Netherland.

Spears, N. and Singh, S. N. (2004). Measuring Attitude Toward the Brand and Purchase Intentions. Journal of Current Issues and Research in Advertising, 26(2), 54-66.

Speck, P., Schumann, D. and Thompson, C. (1988). Celebrity EndorsementsScripts, Schema and Roles: Theoretical Framework and Preliminary Tests. Advances in Consumer Research, 15, 69-76.

Stanley, S.M., Clow, K. and James, K.E. (2011). The Impact Of Visual Strategy and Race and Gender Congruency on Source Credibility of Print Advertisements. The Marketing Management Journal, 21(2), 81-94.

Şimşek, Ö. F. (2007). Yapısal Eşitlik Modellemesine Giriş Temel İlkeler ve LISREL Uygulamaları. Ankara: Ekinox.

Tanjung, S. and Hudrasyah, H. (2016). The Impact Of Celebrity And Non-Celebrity Endorser Credibility In The Advertisement On Attitude Towards Advertisement, Attitude Towards Brand and Purchase Intention. International Conference on Ethics of Business, Economics, and Social Science, 231245.

Turanlı, M., Taşpınar Cengiz, P. ve Bozkır, Ö. (2012). Faktör Analizi İle Üniversiteye Giriş Sınavlarındaki Başarı Durumuna Göre İllerin Sıralanması. İstanbul Üniversitesi İktisat Fakültesi Ekonometri ve İstatistik Dergisi, 17, 45-68.

Van der Waldt, D., Van Loggerenberg. and M., Wehmeyer, L. (2009). Celebrity Endorsements Versus Created Spokespersons in Advertising: A Survey Among Students. SAJEMS, 12(1), 110-114.

Wang, S.W. and Scheinbaum, A.C. (2017). Trustworthiness Trumps Attractiveness and Expertise: Enhancing Brand Credibility Through Celebrity Endorsement. J. Advertising Res., 58(1), 1-42.

Wang, X. (2018). Responses to HIV Public Service Announcements: The Mediating Role of Attitude toward the Ad and Source Identification. Intercultural Communication Studies, 27(1), 114-124.

Wei, P.S. and Lu, H.S. (2013). An Examination of the Celebrity Endorsements and Online Customer Reviews Influence Female Consumers' Shopping Behavior. Computers In Human Behavior, 29, 193-201.

Willemsen, L.M., Neijens, P.C. and Bronner, F. (2012). The Ironic Effect of Source Identification on the Perceived Credibility of Online Product Reviewers. Journal of Computer-Mediated Communication, 18, 16-31. 
Wongweeranonchai, P. and McClelland, R.J. (2016). The Influence of Perceived Celebrity Endorser Credibility in Advertising on Purchase Intention of Thai Consumers. Journal of Communication and Innovation, 3 (2), 115-136.

Yan, Q., Wu, S., Wang, L. Wu, P. Chen, H. and Wei, G. (2016). E-Wom From ECommerce Websites and Social Media: Which Will Consumers Adopt?. Electronic Commerce Research And Applications, 17, 62-73.

Yıldız, E. ve Avc1, İ. (2019). İnstagram Fenomenlerinin Görsel ve Sözel Paylaşımlarının Marka Tutumu, Marka Değiștirme Ve Elektronik Kulaktan Kulağa Pazarlama Üzerine Etkisi. Uluslararası İktisadi ve İdari İncelemeler Dergisi, (25), 179-198.

Zafar, Q.-U. and Rafique, A. (2012). Impact of Celebrity Advertisement on Customers"e Brand Perception and Purchase Intention. Asian Journal of Business and Management Sciences, 1(11), 53-67.

Zang, D. (2014). The Impact of Two-Sided Messaging on Brand Attitude: an Attribution Theory Approach, (Yayımlanmamış Yükseklisans Tezi), Iowa State University, USA.

Zhao, J. (2004). An Experimental Comparison of Celebrity Spokespersons' Credibility, Attractiveness, Expertise, and Identification on Attitudes toward the Ads and Future Interest, (Yayımlanmamış Yükseklisans Tezi), University of Lethbridge, Canada.

Zvinte, I. (2017). The Impact Of Endorser Credibility On Brand Credibilty: The Moderatıng Effect Of Involvement Into The Product Category, (Yayımlanmamış Yükseklisans Tezi), ISM University, Lithuanian. 